\title{
Practical strategies to implement the ESPNIC Nutrition Clinical Recommendations into PICU practice
}

\author{
Lyvonne N Tume ${ }^{1,2}$, Erwin Ista ${ }^{3,4}$, Sascha Verbruggen ${ }^{3}$, Corinne Jotterand Chaparro ${ }^{5}$, Clémence \\ Moullet $^{5}$, Lynne Latten ${ }^{2}$, Luise V. Marino ${ }^{6}$, Frederic V Valla,
}

\section{Author Affiliations}

1. School of Health \& Society, University of Salford, Manchester UK

2. Paediatric Intensive Care Unit, Alder Hey Children's Hospital, Liverpool UK.

3. Intensive Care Unit, Department of Paediatrics and Paediatric Surgery, Erasmus Medical Centre, Sophia Children's Hospital, Rotterdam, the Netherlands

4. Department of Internal Medicine, Nursing Science, Erasmus MC University Medical Center, Rotterdam, The Netherlands.

5. Nutrition and dietetics department, Geneva School of Health Sciences, HES-SO University of Applied Sciences and Arts Western Switzerland

6. Department of Dietetics/ Speech \& Language Therapy, NIHR Biomedical Research Centre Southampton, University Hospital Southampton, Faculty of Environmental \& Life Sciences, University of Southampton, Southampton, UK

7. Paediatric intensive care unit, Hôpital Femme Mère Enfant,

8. CarMEN INSERM UMR, 1060 Hospices Civils de Lyon, Lyon-Bron, France 


\title{
Practical strategies to implement the ESPNIC Nutrition Clinical Recommendations into PICU practice
}

\author{
Abstract \\ Background: The European Society of Pediatric and Neonatal Intensive Care (ESPNIC) published 32 \\ clinical recommendations around supporting nutrition in critically ill children following an extensive \\ review of the literature online in January 2020. The challenge now is to engage with paediatric \\ intensive care unit teams to implement these into their practice.
}

Objective: This practical implementation guide uses a recognised implementation model to guide pediatric intensive care professionals to implement these evidence-based clinical recommendations into clinical practice.

Results and conclusions: We use the Pronovost implementation of evidence into practice model to provide a practical framework with associated documents to facilitate PICU healthcare professional's implementation of these clinical recommendations into PICU practice. The paper is structured around the four steps in this model: summarising the evidence, identifying local barriers to implementation, measuring performance and ensuring all patients receive the intervention and useful checklists for implementation and compliance monitoring are provided, in addition to tables outlining key professional roles and responsibilities around nutrition in the paediatric Intensive care Unit.

Key words: nutrition, child; critically ill; implementation; guidelines 


\section{Introduction}

The European Society of Pediatric and Neonatal Intensive Care (ESPNIC) undertook an evidence synthesis of commonly asked clinical questions and produced clinical recommendations for nutrition practice in critically ill children in 2020 [1]. The challenge now is to implement these into clinical Paediatric Intensive Care Unit (PICU) practice. Research demonstrates that many clinical guidelines are never implemented into practice or there are significant delays in doing so [2]. Guidelines are in themselves supposed to reduce the gap between research evidence and the application of this evidence into clinical practice. Yet even guidelines are not always adequately implemented. Multiple factors contribute to this problem related to several domains such as guideline factors, professional factors (e.g. lack of knowledge, time), organisational factors and clinicians lack of time and skill in effectively implementing a change into practice [2]. Implementation models or frameworks have been developed to aid clinicians in implementing evidence into practice, but they are not always used [3].

To facilitate the implementation of the ESPNIC Nutrition Clinical guidelines we propose to use a recognised implementing framework, Pronovost 2008 [4]. This paper, utilising this framework, provides specific guidance and documents to assist all healthcare professionals involved: physicians, nurses, dietitians and pharmacists in implementing the ESPNIC 2020 clinical recommendations into PICUs. The paper will highlight the different professionals' roles and responsibilities in this implementation process, as effective implementation must be an interdisciplinary process.

\section{The implementation into practice model and process}

Considerable effect has been expended over the last decades in healthcare, and in the field of critical care, to facilitate the translating for research findings into practice $[5,6]$. Evidence of this change were seen as evidence-based guidelines, bundles and protocols, which were developed and 
disseminated to enable the process of change. However, this has not directly changed practice. Changing clinical practice is challenging, and not limited to healthcare professionals (changing behaviour), but also often requires change to organisational processes and technology-based interventions like clinical decision support [7]. Effective implementation of the current nutrition recommendations in PICUs requires a systematic approach with good preparation and planning. There is no 'one size fits all' solution for implementation into all the PICUs across the world, but general principles can be followed. For a successful implementation, the process, should be guided by an implementation process model [8]. Several crucial elements for the successful use of models and frameworks have been identified [9]. Firstly, it is important to consider the complexity of the guideline or intervention in relation to the usual patient care in changing routines in clinical practice. Numerous factors can hinder or facilitate the implementation. A well-planned approach to identify these is helpful. Next, specific attention should be given to the guideline or intervention itself, e.g. the level of evidence and general attractiveness of the product. In preparing the change process attention must be paid to the resources and practical aspects of the implementation (e.g. sufficient expertise). Furthermore, the key stakeholders should be identified, and the target group of professionals, or care providers should be well informed and motivated. Finally, understanding measures of performance in relation to guideline implementation is vital for monitoring the improvement. Only, in this way you can identify if the implementation was successful. Matching specific implementation strategies with the identified barriers and facilitators and considering the development of multiple implementation interventions (activities) is extremely helpful. Newer taxonomies like the Expert Recommendations for Implementing Change (ERIC) [10] and the behaviour change technique taxonomy [11] can assist this.

For the implementation of the ESPNIC Nutritional support for children during critical illness recommendations, we chose the Translating evidence into practice: a model for large scale knowledge translation $[4,12]$. This model has been successfully used in several large-scale implementations in the intensive care units, for example reduction of catheter related blood stream 
infections in intensive care units, and thus staff are familiar with it [13]. Many of the previously described crucial steps, summarizing the evidence, identification of barriers, measuring the performance, stakeholders and the process of implementation are in this model, and it highlights the importance of the development and selection of the implementation strategy.

\section{Step 1 summarising the evidence}

In 2020, a multidisciplinary group of the Nutrition section in ESPNIC published 32 clinical recommendations around supporting nutrition in critically ill children [1]. The group generated 15 commonly asked clinical questions around different aspects of nutrition in critically ill children. A systematic literature search was conducted, and the evidence graded using the Scottish Intercollegiate Guidelines Network (SIGN) grading system.[14] Meta-analyses were conducted where possible, and clinical recommendations were generated which were voted on. This was defined as strong consensus (>95\% agreement) and consensus (>75\% agreement). The 15 clinical questions involved a review of 7261 abstracts, and of these 142 publications were relevant to develop 32 recommendations. Strong consensus was achieved in 21 (66\%) and consensus in 11 (34\%) of the recommendations. Only 11 meta-analyses could be performed on 5 questions. The ESPNIC recommendations have done this step.

\section{Step 2 Identify local barriers to implementation}

The next step before beginning this process in your unit is to form a multidisciplinary implementation group in your unit including nurses, physicians, dietitians and pharmacists. This cannot be done by physicians or dietitians alone. Then begin to identify local barriers to implementation. There are freely available ESPNIC tools allowing you to assess the barriers to delivering adequate enteral nutrition (EN) on your PICU and these are available in 10 common languages and should be completed by as many PICU staff (nurses, physicians, dietitians) as possible https://espnic-online.org/News/Latest-News/Survey-to-identify-the-barriers-to-deliver-enteral- 
nutrition. $[15]$ The analysis of the results of this exercise should be undertaken by the implementation group to consider the barriers you need to focus on in your PICU as provide a baseline against which to assess how effective the process is. A suggested checklist is provided for each of the ESPNIC recommendations and the factors to consider regarding equipment, staff skills and expertise, guidance available (Electronic Supplementary File 1). As a group, you should consider whether you can implement all the recommendations at once or undertake it in a staged process and then develop an implementation plan with realistic timescale for this process.

Evidence suggests that rewriting your local unit guidelines incorporating the new recommendations in a manner which fits with the processes in your unit is likely to be most effective [16]. These guidelines should be short, easily accessible, understandable and easy to follow by bedside staff. If bedside staff cannot easily access guidelines they will not be followed. Consider at this point how you are going to educate all the PICU team about new guidance. Every unit will differ in the way they do this, it may be at induction training, mandatory training, at the bedside or by unit seminars. It is useful to identify the 'informal leaders and influencers' in your unit, these may not be the managers or chiefs, but are people, that influence others, and if you can get them 'on board', others will follow $[17,18]$. It is most effective to highlight specific disciplines roles and responsibilities in the implementation process so immediately staff can see what applied directly to them (Tables $\mathbf{1 , 2 , 3 )}$ The bedside nurses' role is crucial in delivering nutrition in the PICU. The bedside nurse assesses readiness of the child for the initiation of EN ( 24 hours a day), often prompts the physician or nurse practitioner to prescribe feeds (if this is required), prepares and delivers enteral or parenteral nutrition and assess the child's ongoing 'tolerance' of enteral feeding, and escalates the feed volume to achieve the target set by the dietitian (Table 1). No other professional is at the child's bedside constantly and in this position, thus failing to involve nurses in nutrition protocol development and implementation are certain to lead to ineffective implementation and poor compliance. 
Physicians also play a major role in nutritional care in PICU. Their role is shared with dietitians, pharmacists (for parenteral nutrition) and nurses, depending on local organisation and roles within the country. They should be directly involved in integrating nutritional care into the holistic care of the critically ill child (Table 2). They are in a position to confirm the indications and potential contra indications to EN, balance nutrition with fluid goals, ensure that patient is equipped with adequate feeding access (gastric or post pyloric tube in case of EN or central venous access in case of parenteral nutrition), and confirm signs of feed intolerance. Ideally, nutrition should be prescribed, and fluid balance and nutritional goals should be monitored daily to ensure that the patient receives what is prescribed. Physicians should consider nutrition as an important supportive care that influences long term outcomes; however improved education is recommended.

Dietitians are also a key professional in optimising nutrition in the critically ill child. Many (but not all) PICUs have a dedicated PICU dietitian, with an average of 0.4 whole-time equivalent position per ten beds, which was an independent predictor of optimal enteral protein intake $[19,20]$. However, as dietitians are not constantly present in the PICU, in addition to monitoring for adequate nutritional prescription and delivery (Table 3), they should have a leadership role in nutrition education and encourage inter-professional practices [21]. They should be proactive in developing strategies to make the clinical team more aware of nutrition and increase their nutritional knowledge and skills. In collaboration with others, dietitians should ideally lead the development and implementation of a nutritional protocol, education on nutrition for healthcare professionals or a nutrition section in the computerised system (including energy and protein goals, nutrition balance or deficit).

Some staff in any unit will be resistant to change, and it may take considerable time and effort to influence and persuade these staff. This may be best done personally, as opposed to in a group. Human nature necessitates that all staff will need reminders when a practice changes, so consider how best to 'remind' staff in your PICU. This might be at the bedside computer (screen savers), in the staff room or handover over or paper signs at the bedside. Once you have your implementation 
plan, with a realistic time frame agreed, and a date to begin when key implementation people in the group are available you are ready to begin.

\section{Step 3 Measuring performance}

Healthcare professionals will not automatically follow new guidelines or processes, human nature demonstrates that people will often fall back to what they are used to doing, thus measuring how well the new guidelines are being followed is essential, as well as the outcomes intended by implementation of the new recommendations. Once you have your plan and have started to implement this, you will need to consider how you will evaluate the uptake/compliance with clinical recommendations. The first step is select key performance indicators, against which to evaluate the effectiveness of your implementation [22,23], alongside the level of adherence that is considered 'successful' (Electronic Supplementary File 2). It is recommended to start with 5-8 of the performance indicators listed first, rather than attempting to address all of these at once, and the choice of these should be tailored to address specific issues in your unit. Consideration needs to be given to the frequency of compliance monitoring, who will do this monitoring, when and how they will do it. Crucially, these results must be feedback to the team, so consider how these results will be shared with the whole PICU team and specific staff groups. Health records, electronic systems may need to be altered to reflect the new guidance and make auditing compliance easier. Electronic supplementary file 2 provides an example audit checklist for guideline compliance.

\section{Step 4 Ensure all patients reliably receive the intervention}

The Pronovost implementation model claims this is the most complex stage of the implementation process [4]. This stage reflects efforts to embed the new recommendations and guidance into the local PICU systems. This model recommends the four 'Es' approach: engage, educate, execute and evaluate. These have been discussed with some examples and practical considerations. It is worthwhile stating that during the first weeks of active implementation it is essential that the implementation group and 'champions' are around and available, both for questions, to act as a 
reminder and to encourage enforcement. Following this, the proposed framework added another relevant ' $E$ ' endure. Endure relates to sustaining the intervention by ensuring it is incorporated into local systems and local existing quality improvement processes. Measuring the compliance of the performance indicators over time will ensure sustainability. Normalisation process theory [16] describes how complex interventions such as this, become 'normalised' into usual clinical care processes and work, and this often takes some time. Using elements of this sociological model, combined with the Pronovost model allows us to understand and consider some of the dynamic processes that assist or hinder new interventions becoming embedded into everyday clinical practice.

\section{Conclusions}

This practical implementation paper uses a recognised implementation model to guide paediatric intensive care professionals in a step by step manner, providing examples of checklists for effective implementation and highlighting the role of all professional groups in the implementation of these evidence-based clinical recommendations into clinical practice. 


\section{References:}

1.Tume LN, Valla FV, Joosten $\mathrm{K}$ et al. Nutritional support for children during critical illness: European Society of Pediatric and Neonatal Intensive Care (ESPNIC) Metabolism, Endocrine and Nutrition section Position statement and Clinical Recommendations. Intensive Care Medicine 2020; DOI https://doi.org/10.1007/s00134-019-05922-5

2.Flottorp SA, Oxman AD, Krause J, et al. A checklist for identifying determinants of practice: a systematic review and synthesis of frameworks and taxonomies of factors that prevent or enable improvements in healthcare professional practice. Implement Sci. 2013;8:35. Published 2013 Mar 23. doi:10.1186/1748-5908-8-35

3. Nilsen P. Making sense of implementation theories, models and frameworks. Implement Sci. 2015;10:53. Published 2015 Apr 21. doi:10.1186/s13012-015-0242-0

4. Pronovost PJ, Berenholtz SM, Needham DM. Translating evidence into practice: a model for large scale knowledge translation. BMJ 2008; 337: a1714

5. Lagu T. Translating knowledge into practice in critical care settings*. Crit Care Med. 2013;41(11):2659-2660. doi:10.1097/CCM.0b013e31829e4cab

6. Wallace DJ. Strategies to effect change in the ICU. Curr Opin Crit Care. 2019;25(5):511-516. doi:10.1097/MCC.0000000000000647

7 Rosa RG, Teixeira C, Sjoding M. Novel approaches to facilitate the implementation of guidelines in the ICU [published online ahead of print, 2020 Jul 17]. J Crit Care. 2020;60:1-5.

doi:10.1016/j.jcrc.2020.07.014

8.Tabak, R.G., et al., Bridging research and practice: models for dissemination and implementation research. Am J Prev Med, 2012. 43(3): p. 337-50.

9. Grol, R., M. Wensing, and M. Eccles, Improving Patient Care; The Implementation of Change in Clinical Practice. Vol. 2nd Revised version. 2013, London: Elsevier.

10. Powell, B.J., et al., A refined compilation of implementation strategies: results from the Expert Recommendations for Implementing Change (ERIC) project. Implement Sci, 2015. 10: p. 21.

11. Michie, S., et al., The behavior change technique taxonomy (v1) of 93 hierarchically clustered techniques: building an international consensus for the reporting of behavior change interventions. Ann Behav Med, 2013. 46(1): p. 81-95.

12. Patient safety, quality of care, and knowledge translation in the intensive care unit. Respiratory care, 2010. 55(7): p. 922-8.

13. Pronovost, P., et al., An intervention to decrease catheter-related bloodstream infections in the ICU. The New England journal of medicine, 2006. 355(26): p. 2725-32.

14. Scottish Intercollegiate Guidelines Network (SIGN) Grading https://www.sign.ac.uk/assets/sign grading system 1999 2012.pdf

15. ESPNIC Barriers to delivering Enteral Nutrition in PICUs quality improvement tool https://espniconline.org/News/Latest-News/Survey-to-identify-the-barriers-to-deliver-enteral-nutrition. Available on ESPNIC website

16. Murray, E., Treweek, S., Pope, C. et al. Normalisation process theory: a framework for developing, evaluating and implementing complex interventions. BMC Med 8, 63 (2010). https://doi.org/10.1186/1741-7015-8-63 
17. S Ash, P.Zoë Stavri, Richard Dykstra, Lara Fournier, Implementing computerized physician order entry: the importance of special people, International Journal of Medical Informatics, Volume 69, Issues 2-3,

18. Hegarty J, Murphy S, Creedon S, et al Leadership perspective on the implementation of guidelines on healthcare-associated infections BMJ Leader 2019;3:43-51.

19. Mehta NM, Bechard L, Cahill N, et al. Nutritional practices and their relationship to clinical outcomes in critically ill children--an international multicenter cohort study*. Crit Care Med. 2012;40(7):2204-2211. doi:10.1097/CCM.0b013e31824e18a8

20. Mehta NM, Bechard L, Zurakowski D, Duggan CP, Heyland DK. Adequate enteral protein intake is inversely associated with 60-d mortality in critically ill children: a multicenter, prospective, cohort study. Am J Clin Nutr. 2015;102(1):199-206. doi:10.3945/ajcn.114.104893

21. Hark LA, Deen D. Position of the Academy of Nutrition and Dietetics: Interprofessional Education in Nutrition as an Essential Component of Medical Education. J Acad Nutr Diet. 2017;117(7):11041113. doi:10.1016/j.jand.2017.04.019

22. Weiss $\mathrm{CH}$, Krishnan JA, Au DH, et al. An Official American Thoracic Society Research Statement: Implementation Science in Pulmonary, Critical Care, and Sleep Medicine. Am J Respir Crit Care Med. 2016;194(8):1015-1025. doi:10.1164/rccm.201608-1690ST

17. Proctor, E., et al., Outcomes for implementation research: conceptual distinctions, measurement challenges, and research agenda. Adm Policy Ment Health, 2011. 38(2): p. 65-76.\} 
Figure 1

Strategy for translating evidence into practice.

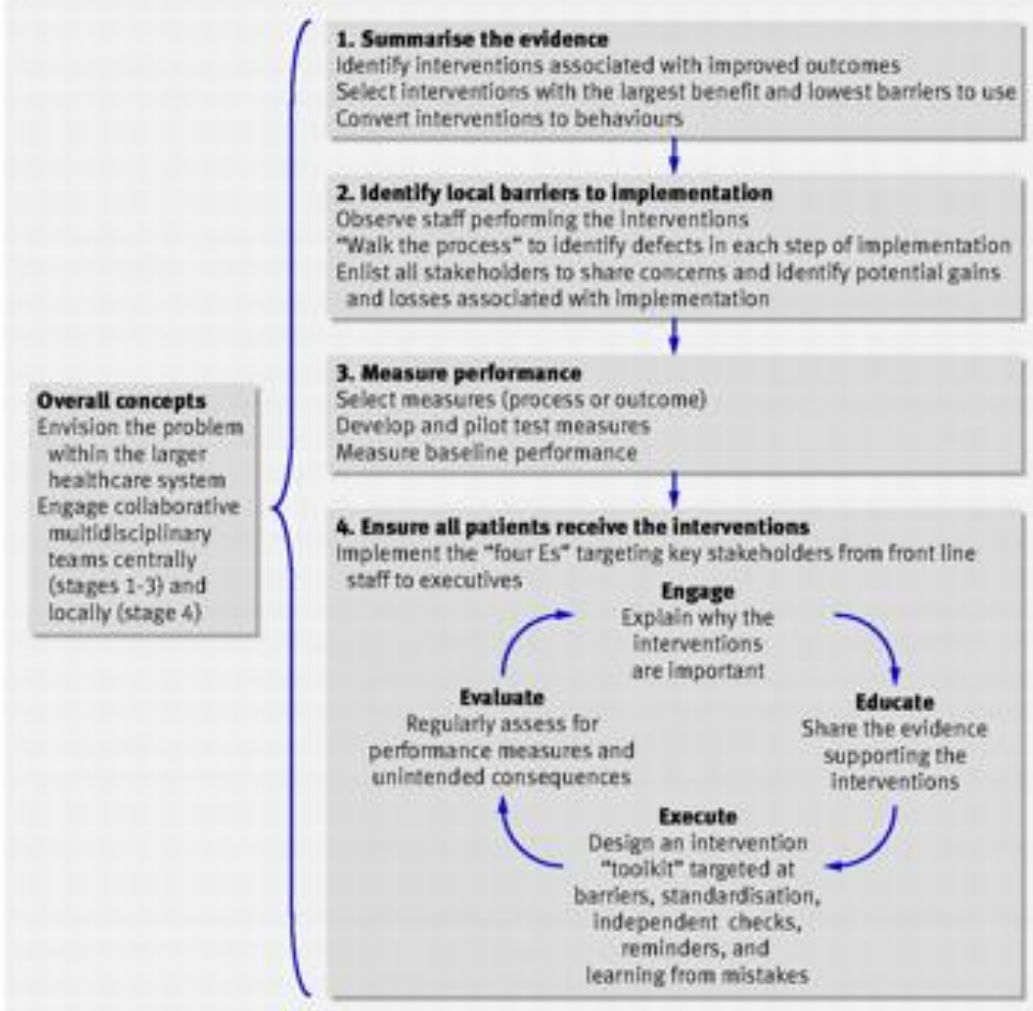

Peter J Pronovost et al. BMJ 2008;337:bmj.a1714 
Table 3a Suggested nursing implementation responsibilities relating to implementation of ESPNIC nutrition recommendations (role may vary by unit and country)

\section{At (or within 6 hours of) admission}

- Insert gastric feeding tube/confirm correct position

- Record accurate weight and length taken soon after admission

- Some nurses/staff may be trained to undertake more detailed anthropometric measurements

- Think about starting some enteral feeding (even small trophic amounts) as soon as possible and prompt the medical teams if an order to start feeds is needed

\section{During the PICU stay}

- Ensure regular (minimum twice weekly) weights are taken throughout the child's PICU stay and weekly head circumference for children $<2$ years

- Assess and monitor tolerance of enteral feeding, but do not base decisions solely on gastric residual volume (gastric aspirate volumes) other factors such as abdominal signs (abdominal distention and/or pain), vomiting, diarrhoea, presence of bowel sounds should be used.

- Advanced enteral feeding as per unit protocol/guidelines

- Reduce fasting times for procedures to minimal or coordinate child's car/interventions to try and cluster multiple procedures at the same time if possible

\section{In general}

- Get involved in writing and/or implementing unit-based feeding guidelines or if one already exists, ensure it is followed and make others aware of it and endure the unit protocol is updated reflecting best current evidence 
Table 3b Suggested physician implementation responsibilities relating to implementation of ESPNIC nutrition recommendations (role may vary by unit or country)

\section{Prior to elective PICU admission}

- liaise with paediatricians in charge of pre PICU care (elective surgery) to ensure that nutritional status is assessed, and malnutrition detected to initiate nutritional support prior to surgery and PICU admission

\section{At (or within 6 hours of) admission}

- $\quad$ prescribe early EN but if contraindicated (look for contra indications)

- Assess nutritional status based on anthropometric measurements obtained at admission, and recorded prior to PICU admission, understanding the underlying pathophysiology; consider risk of refeeding syndrome I case of severe undernutrition

- Determine nutritional goals (energy, protein) and prescribe nutrition support accordingly

\section{During the PICU stay}

- Monitor nutrition efficiency (nutritional status monitoring) to limit energy deficit after the acute phase

- Update nutritional goals based on the child clinical state (stable phase, recovery)

- Ensure progressive increase of nutrition support to reach determined goals

- Prescribe nutritional support accordingly

- Assess and monitor tolerance of feeding, base this on validated symptoms according to local protocol

- Distinguish feed related intolerance that may require feed discontinuation from non-feed related intolerance signs that require specific treatments 'withdrawal syndrome, gut infection, etc.)

- Reduce fasting times for procedures to minimal or coordinate child's car/interventions to try and cluster multiple procedures at the same time if possible

- Monitor fluid balance; try not to compromise nutrition goal achievement while fluid over restricting critically ill children

\section{At PICU Discharge}

- Liaise with paediatricians in charge of post ICU care, so that nutritional status is still monitored, and nutritional support maintained when required

- Develop collaboration with paediatric wards to enhance awareness of frequent PICU acquired weakness and nutritional deterioration

In general

- Get involved in writing and/or implementing unit-based feeding guidelines or if one already exists, ensure it is followed and make others aware of it and endure the unit protocol is updated reflecting best current evidence 
Table 3c Suggested dietitian responsibilities relating to implementation of ESPNIC nutrition recommendations (role may vary by unit or country)

Within one registered dietitian working day: Complete a full nutritional assessment, using an $A B C D E$ approach, namely: anthropometry, biochemistry, clinical, dietary and evaluation/ plan.

\section{At (or within 6 hours of) admission}

- Anthropometry: Verify nutritional status of patients, completing a thorough nutrition assessment. Obtain anthropometric measurements, plotting measurements on World Health Organisation/ National growth charts and z-scores to classify and characterise nutrition status.

- Biochemistry: Review relevant biochemistry relating to organ function.

- Clinical: Characterise the phase of critical illness e.g. acute, stable or recovery in addition to other clinical factors, which may affect the route of nutrition support and nutritional needs.

- Dietary: If caregivers are present, obtain a recent dietary/feeding history. Identify outcomes of nutrition support.

Determine nutrition energy and protein goals, using predictive equations for energy (e.g. Schofield equations).

Confirm enteral feeds have been started.

Review fluid restrictions with physicians and determine the most appropriate type of enteral feed and route to be used.

- Evaluation: Complete a regular nutrition care plan review providing nutrition support goals in line with defined nutrition outcomes.

\section{During the PICU stay}

- Anthropometry: Anthropometrical measures should be completed regularly e.g. once per week and include weight, length, and head circumference for children $<2$ years and plotted on appropriate growth charts.

- Biochemistry: Review relevant biochemistry relating to organ function

- Clinical: Regularly review the phase of critical illness e.g. acute, stable or recovery.

- Dietary: Regularly re-calculate energy and protein goals

If necessary, measure resting energy expenditure using a validated indirect calorimeter, if available. Check that fasting times for procedures are minimal or that child's interventions are coordinated to try and cluster multiple procedures at the same time if possible.

Check that the type of enteral formula is appropriate.

Identify nutrition goals and outcomes of nutrition support.

- Evaluation: Complete a regular nutrition care plan review providing nutrition support goals in line with defined nutrition outcomes.

Check the nutritional intake (macro- and micronutrients) received daily by patients including intakes from medications. Check the daily energy and protein balances and the cumulative balances. In case of large negative energy and protein deficits, verify the interruptions of enteral nutrition and their reasons. If the interruptions are not necessary, discuss them with the medical and nursing team.

\section{At PICU Discharge}

- Anthropometry: Ensure patients with poor nutritional status receive adequate nutrition support from appropriate trained health care professionals.

- Biochemistry: Confirm micronutrient status if there is poor growth post-PICU discharge.

- Clinical/Dietary: Providing enough macro- and micronutrients to support nutritional rehabilitation during the recovery period.

- Evaluation: Complete a regular nutrition care plan review providing nutrition support goals in line with defined nutrition outcomes. Ensure there is an exit strategy for nutrition support. 
Electronic Supplementary File 1: Checklist for implementation of ESPNIC Clinical Guidelines around Nutrition

\begin{tabular}{|c|c|c|c|}
\hline $\begin{array}{l}\text { ESPNIC Clinical } \\
\text { Recommendations for } \\
\text { Nutritional Support in } \\
\text { PICU }\end{array}$ & Equipment and staff skills & $\begin{array}{l}\text { Staff } \\
\text { involved }\end{array}$ & Tools / other \\
\hline $\begin{array}{l}\text { 1.1 The assessment of } \\
\text { nutritional status is } \\
\text { recommended in } \\
\text { critically ill children at } \\
\text { admission and } \\
\text { throughout their PICU } \\
\text { admission }\end{array}$ & $\begin{array}{l}\text { No validated nutritional risk scores for } \\
\text { tools for PICU patients } \\
\text { Nutritional assessment: using } \\
\text { accurate weight, height and } \\
\text { anthropometry and clear definition of } \\
\text { undernutrition and overnutrition }\end{array}$ & $\begin{array}{l}\text { Nurses, } \\
\text { dietitians, } \\
\text { physicians }\end{array}$ & $\begin{array}{l}\text { Nutritional assessment: Mehta et al } 2013 \text { Defining Pediatric } \\
\text { Malnutrition A Paradigm Shift Toward Etiology-Related } \\
\text { Definitions }\end{array}$ \\
\hline $\begin{array}{l}1.2 \text { It is recommended } \\
\text { to perform } \\
\text { anthropometric } \\
\text { measurements on } \\
\text { admission and regularly } \\
\text { during admission, and } \\
\text { to express these } \\
\text { measurements in z- } \\
\text { scores, including } \\
\text { weight, height/length } \\
\text { mid upper arm } \\
\text { circumference and } \\
\text { head circumference in } \\
\text { young children }\end{array}$ & $\begin{array}{l}\text { 1. Enough scales for both infants and } \\
\text { older children? Ideally weighing scales } \\
\text { integrated to beds } \\
\text { 2. Nurses have skill and confidence to } \\
\text { weigh intubated children? } \\
\text { 3. Nurses or support staff measure } \\
\text { length accurately } \\
\text { 4. Nurses regularly measure head } \\
\text { circumference in children }<4 \text { years } \\
\text { 5. Staff have skills and equipment to } \\
\text { undertake anthropometric } \\
\text { measurements? } \\
\text { 6. Reference values: national growth } \\
\text { curves, or World Health Organization. } \\
\text { Calculation of nutritional indices (z- } \\
\text { scores) }\end{array}$ & $\begin{array}{l}\text { Dietitians, } \\
\text { nurses, } \\
\text { support staff }\end{array}$ & $\begin{array}{l}\text { Place in medical/nursing admission collect and record these } \\
\text { measurements } \\
\text { Tick box for completion for audit purposes } \\
\text { Do high risk children trigger a referral to dietitian? } \\
\text { Published nurse training program on anthropometry } \\
\text { https://journals.lww.com/pccmjournal/Abstract/2015/03000/A } \\
\text { Training Program for Anthropometric Measurements.23.asp } \\
\underline{x} \\
\text { Refer to national growth curves or use WHO: ANTHRO and } \\
\text { ANTHROplus software (free to download and use on WHO } \\
\underline{\text { website) }}\end{array}$ \\
\hline
\end{tabular}




\begin{tabular}{|c|c|c|c|}
\hline $\begin{array}{l}\text { ESPNIC Clinical } \\
\text { Recommendations for } \\
\text { Nutritional Support in } \\
\text { PICU }\end{array}$ & Equipment and staff skills & $\begin{array}{l}\text { Staff } \\
\text { involved }\end{array}$ & Tools / other \\
\hline & $\begin{array}{l}\text { 7. Staff have knowledge to interpret } \\
\text { measured values and calculated } \\
\text { nutritional indices }\end{array}$ & & \\
\hline $\begin{array}{l}2.1 \text { It is recommended } \\
\text { to commence early } \\
\text { enteral nutrition within } \\
24 \text { hours of admission } \\
\text { unless contraindicated }\end{array}$ & $\begin{array}{l}\text { Intubated children (who cannot eat } \\
\text { orally) have feeding tube placed } \\
\text { within } 4 \text { hours of admission? } \\
\text { Variable age feeds available on the } \\
\text { unit? } \\
\text { Newly delivered mothers encouraged } \\
\text { to express and store breast milk? } \\
\text { Are there breast pumps on the unit } \\
\text { and equipment and area for } \\
\text { expressing? } \\
\text { Enough feeding pumps if continuous } \\
\text { feeding used? } \\
\text { Enteral nutrition solutions and infant } \\
\text { formula available on the ward or } \\
\text { rapidly available }\end{array}$ & $\begin{array}{l}\text { Physicians, } \\
\text { nurses, } \\
\text { dietitians }\end{array}$ & $\begin{array}{l}\text { Use a simple written protocol to ensure this happens based on } \\
\text { certain agreed criteria } \\
\text { Using a protocol can significantly reduce the time to first } \\
\text { feeding }\end{array}$ \\
\hline $\begin{array}{l}2.2 \text { It is recommended } \\
\text { to increase enteral } \\
\text { nutrition in a stepwise } \\
\text { fashion until goal for } \\
\text { delivery is achieved } \\
\text { using a feeding } \\
\text { protocol or guideline }\end{array}$ & $\begin{array}{l}\text { Is there a simple feeding algorithm or } \\
\text { flowchart for your unit? } \\
\text { Education of staff around the } \\
\text { flowchart? } \\
\text { Is this flowchart at each bedside for } \\
\text { nurses to follow? } \\
\text { A dietitian or physician sets energy } \\
\text { goals within } 12 \text { hours of admission? }\end{array}$ & All & $\begin{array}{l}\text { Use a simple written protocol with clear feed advancement } \\
\text { guidance }\end{array}$ \\
\hline $\begin{array}{l}3.1 \text { Early enteral } \\
\text { nutrition is }\end{array}$ & $\begin{array}{l}\text { Once hemodynamics stable and } \\
\text { serum lactate below an acceptable }\end{array}$ & All & $\begin{array}{l}\text { Some PICUs find it useful to use a high-risk abdomen protocol in } \\
\text { these children for feeding }\end{array}$ \\
\hline
\end{tabular}




\begin{tabular}{|c|c|c|c|}
\hline $\begin{array}{l}\text { ESPNIC Clinical } \\
\text { Recommendations for } \\
\text { Nutritional Support in } \\
\text { PICU }\end{array}$ & Equipment and staff skills & $\begin{array}{l}\text { Staff } \\
\text { involved }\end{array}$ & Tools / other \\
\hline $\begin{array}{l}\text { recommended in term } \\
\text { neonates who are } \\
\text { stable on ECLS }\end{array}$ & $\begin{array}{l}\text { level and no obvious gut concerns eg } \\
\text { bleeding start trophic enteral feeds } \\
\text { preferably with breast milk }\end{array}$ & & \\
\hline $\begin{array}{l}3.3 \text { Early enteral } \\
\text { nutrition is } \\
\text { recommended in term } \\
\text { neonates who are } \\
\text { stable on } \\
\text { pharmaceutical } \\
\text { hemodynamic support }\end{array}$ & $\begin{array}{l}\text { Once hemodynamics stable and } \\
\text { serum lactate within normal range } \\
\text { and no obvious gut concerns eg } \\
\text { bleeding start trophic enteral feeds } \\
\text { preferably with breast milk }\end{array}$ & All & As above \\
\hline $\begin{array}{l}\text { 3.4 Early enteral } \\
\text { nutrition is } \\
\text { recommended in } \\
\text { children who are stable } \\
\text { on pharmaceutical } \\
\text { hemodynamic support }\end{array}$ & $\begin{array}{l}\text { Once hemodynamics stable and } \\
\text { serum lactate within normal range } \\
\text { and no obvious gut concerns eg } \\
\text { bleeding start trophic enteral feeds }\end{array}$ & All & As above \\
\hline $\begin{array}{l}3.5 \text { Early enteral } \\
\text { nutrition is } \\
\text { recommended in }\end{array}$ & & $\begin{array}{l}\text { All and } \\
\text { cardiac } \\
\text { surgeons }\end{array}$ & \\
\hline
\end{tabular}




\begin{tabular}{|c|c|c|c|}
\hline $\begin{array}{l}\text { ESPNIC Clinical } \\
\text { Recommendations for } \\
\text { Nutritional Support in } \\
\text { PICU }\end{array}$ & Equipment and staff skills & $\begin{array}{l}\text { Staff } \\
\text { involved }\end{array}$ & Tools / other \\
\hline \multicolumn{4}{|l|}{$\begin{array}{l}\text { children after cardiac } \\
\text { surgery }\end{array}$} \\
\hline $\begin{array}{l}\text { 4.1 Enteral nutrition } \\
\text { should be considered in } \\
\text { term neonates with } \\
\text { umbilical arterial } \\
\text { catheters }\end{array}$ & & $\begin{array}{l}\text { All and } \\
\text { cardiac } \\
\text { surgeons }\end{array}$ & $\begin{array}{l}\text { Some units prefer to use a high-risk abdomen protocol to feed } \\
\text { these infants }\end{array}$ \\
\hline $\begin{array}{l}\text { 4.2 Enteral nutrition } \\
\text { should be considered in } \\
\text { critically ill term } \\
\text { neonates on PGE1 } \\
\text { infusion if managed in } \\
\text { a critical care unit with } \\
\text { adequate observation } \\
\text { and monitoring }\end{array}$ & $\begin{array}{l}\text { Start trophic feeing preferably with } \\
\text { breast milk whist ensuring ongoing } \\
\text { monitoring of hemodynamics (pre } \\
\text { and post ductal saturations), blood } \\
\text { pressure (especially diastolic BP) } \\
\text { blood gases (watch lactate) and } \\
\text { abdomen }\end{array}$ & $\begin{array}{l}\text { All and } \\
\text { cardiac } \\
\text { surgeons }\end{array}$ & $\begin{array}{l}\text { Some units prefer to use a high-risk abdomen protocol to feed } \\
\text { these infants }\end{array}$ \\
\hline $\begin{array}{l}5.1 \text { In the acute phase, } \\
\text { energy intake provided } \\
\text { to critically ill children } \\
\text { should not exceed } \\
\text { resting energy } \\
\text { expenditure }\end{array}$ & $\begin{array}{l}\text { Start with trophic (permissive } \\
\text { underfeeding or non-nutritive feeds) } \\
\text { with age-appropriate feed or breast } \\
\text { milk in neonates if available }\end{array}$ & $\begin{array}{l}\text { Dietitians } \\
\text { and } \\
\text { physicians }\end{array}$ & $\begin{array}{l}\text { Link to the recommended energy estimation formula } \\
\text { https://www.dieteticpocketguide.com/energy_requirements_c } \\
\text { hildren/ }\end{array}$ \\
\hline $\begin{array}{l}5.2 \text { After the acute } \\
\text { phase, energy intake } \\
\text { provided to critically ill }\end{array}$ & & $\begin{array}{l}\text { Dietitians } \\
\text { and } \\
\text { physicians }\end{array}$ & $\begin{array}{l}\text { Link to the recommended energy estimations } \\
\text { https://link.springer.com/article/10.1007/s00134-019-05922-5 }\end{array}$ \\
\hline
\end{tabular}




\begin{tabular}{|c|c|c|c|}
\hline $\begin{array}{l}\text { ESPNIC Clinical } \\
\text { Recommendations for } \\
\text { Nutritional Support in } \\
\text { PICU }\end{array}$ & Equipment and staff skills & $\begin{array}{l}\text { Staff } \\
\text { involved }\end{array}$ & Tools / other \\
\hline $\begin{array}{l}\text { children should } \\
\text { account for energy } \\
\text { debt, physical activity, } \\
\text { rehabilitation and } \\
\text { growth }\end{array}$ & & & $\begin{array}{l}\text { https://www.dieteticpocketguide.com/energy_requirements_c } \\
\text { hildren/ }\end{array}$ \\
\hline $\begin{array}{l}\text { 6.1 Measuring resting } \\
\text { energy expenditure } \\
\text { using a validated } \\
\text { indirect calorimeter } \\
\text { should be considered } \\
\text { to guide nutritional } \\
\text { support in critically ill } \\
\text { infants and children } \\
\text { after the acute phase }\end{array}$ & $\begin{array}{l}\text { Is indirect calorimetry possible in your } \\
\text { unit? } \\
\text { Consider: Which age/weight range } \\
\text { does your indirect calorimeter cover? } \\
\text { Is it validated in pediatrics and PICU? }\end{array}$ & $\begin{array}{l}\text { Dietitians } \\
\text { and } \\
\text { physicians }\end{array}$ & $\begin{array}{l}\text { Link to the recommended energy estimations } \\
\text { https://link.springer.com/article/10.1007/s00134-019-05922-5 }\end{array}$ \\
\hline $\begin{array}{l}6.2 \text { Schofield equation } \\
\text { (for age and gender } \\
\text { and using an accurate } \\
\text { weight) is } \\
\text { recommended to } \\
\text { estimate resting energy } \\
\text { expenditure }\end{array}$ & $\begin{array}{l}\text { Dietitian or physician to use Schofield } \\
\text { equation to estimate energy } \\
\text { requirements in the acute phase } \\
\text { aiming for no more than } 2 / 3 \text { of this } \\
\text { target by } 72 \text { hours after admission }\end{array}$ & $\begin{array}{l}\text { Dietitians } \\
\text { and } \\
\text { physicians }\end{array}$ & $\begin{array}{l}\text { Link to the recommended energy estimations } \\
\text { https://link.springer.com/article/10.1007/s00134-019-05922-5 }\end{array}$ \\
\hline $\begin{array}{l}\text { 7.1 Parenteral glucose } \\
\text { provision should be } \\
\text { sufficient to avoid }\end{array}$ & $\begin{array}{l}\text { Regular monitoring of serum glucose } \\
\text { in critically ill children either on blood } \\
\text { gas or glucometer }\end{array}$ & $\begin{array}{l}\text { Dietitians, } \\
\text { pharmacists, } \\
\text { physicians }\end{array}$ & $\begin{array}{l}\text { Recommended PN guidance } \\
\text { ESPGHAN/ESPEN/ESPR/CSPEN guidelines on pediatric } \\
\text { parenteral nutrition: Carbohydrates. Clin Nutr. 2018;37(6 Pt } \\
\text { B):2337-43. }\end{array}$ \\
\hline
\end{tabular}




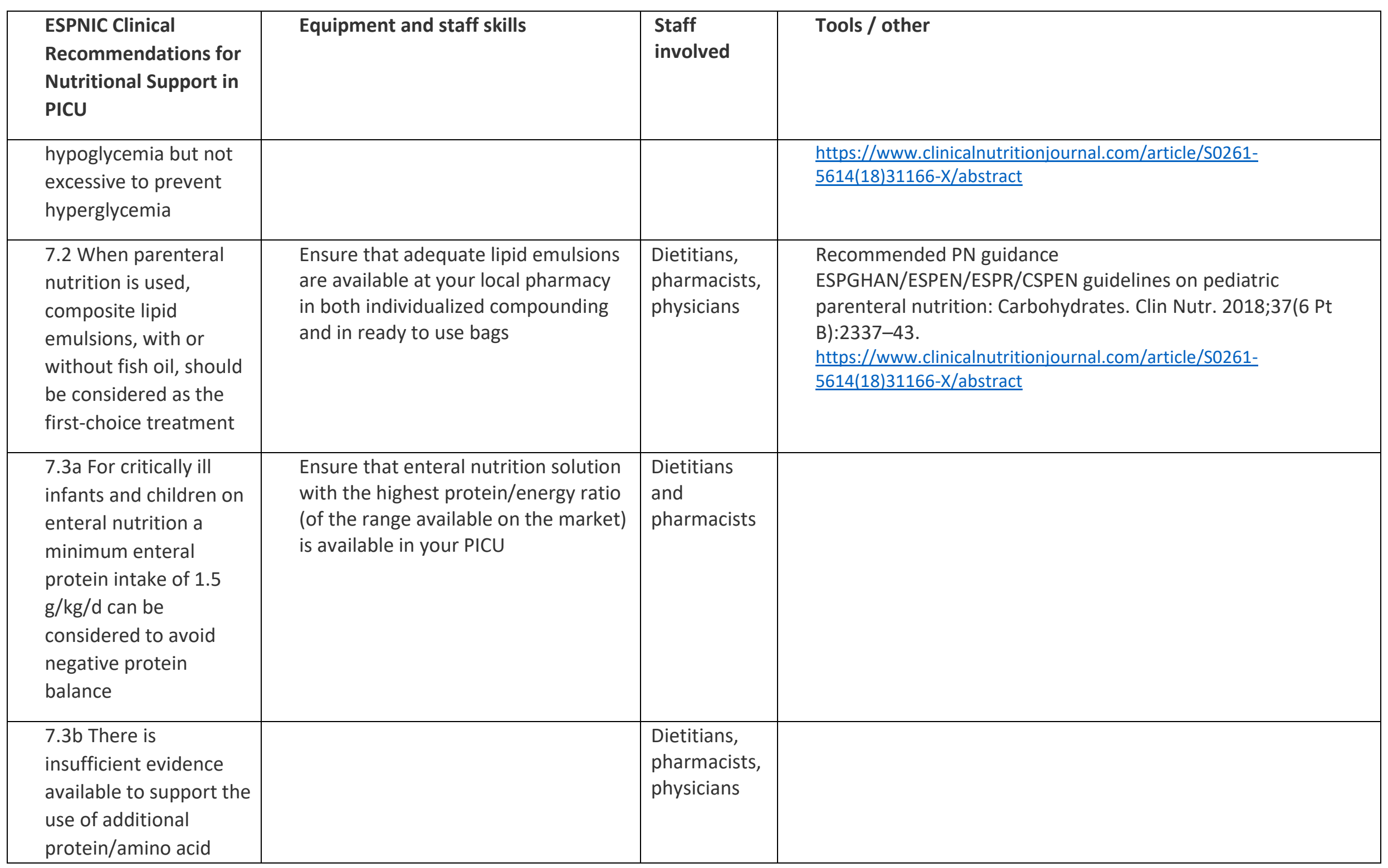




\begin{tabular}{|c|c|c|c|}
\hline $\begin{array}{l}\text { ESPNIC Clinical } \\
\text { Recommendations for } \\
\text { Nutritional Support in } \\
\text { PICU }\end{array}$ & Equipment and staff skills & $\begin{array}{l}\text { Staff } \\
\text { involved }\end{array}$ & Tools / other \\
\hline $\begin{array}{l}\text { intake during the acute } \\
\text { phase of illness (Strong } \\
\text { consensus) }\end{array}$ & & & \\
\hline $\begin{array}{l}8.1 \text { Polymeric feeds } \\
\text { should be considered } \\
\text { as the first choice for } \\
\text { enteral nutrition in } \\
\text { most critically ill } \\
\text { children, unless there } \\
\text { are contraindications }\end{array}$ & $\begin{array}{l}\text { Ensure HCP are familiar with EN } \\
\text { terminology, and capable of } \\
\text { differentiating between polymeric, } \\
\text { semi elemental and elemental } \\
\text { formulas }\end{array}$ & All & $\begin{array}{l}\text { Short education sessions should be delivered to all HCP } \\
\text { involved in nutrition }\end{array}$ \\
\hline $\begin{array}{l}8.2 \text { Protein and energy- } \\
\text { dense formulations } \\
\text { may be considered to } \\
\text { support achievement } \\
\text { of nutritional } \\
\text { requirements in fluid- } \\
\text { restricted critically ill } \\
\text { children }\end{array}$ & $\begin{array}{l}\text { Is the child fluid restricted? Eg after } \\
\text { heart surgery } \\
\text { Fluid balance monitoring mandatory } \\
\text { in PICU }\end{array}$ & All & $\begin{array}{l}\text { Nurses should also consider concentrating drug infusions to } \\
\text { allow for the maximal amount of enteral nutrition to be } \\
\text { delivered } \\
\text { Work with physicians and pharmacists to get these prescribed } \\
\text { in a concentrated form and remember to label clearly that it is } \\
\text { not standard concentration to avoid drug errors }\end{array}$ \\
\hline $\begin{array}{l}\text { 8.3 Peptide-based } \\
\text { formulations may be } \\
\text { considered to improve } \\
\text { tolerance and } \\
\text { progression of enteral } \\
\text { feeding in children for }\end{array}$ & $\begin{array}{l}\text { Ensure HCP are familiar with EN } \\
\text { terminology, and capable of } \\
\text { differentiating between polymeric, } \\
\text { semi elemental (extensively } \\
\text { hydrolysed) and elemental formulas } \\
\text { Ensure semi elemental formulas are } \\
\text { available }\end{array}$ & All & $\begin{array}{l}\text { Short education sessions should be delivered to all HCP } \\
\text { involved in nutrition }\end{array}$ \\
\hline
\end{tabular}




\begin{tabular}{|c|c|c|c|}
\hline $\begin{array}{l}\text { ESPNIC Clinical } \\
\text { Recommendations for } \\
\text { Nutritional Support in } \\
\text { PICU }\end{array}$ & Equipment and staff skills & $\begin{array}{l}\text { Staff } \\
\text { involved }\end{array}$ & Tools / other \\
\hline \multicolumn{4}{|l|}{$\begin{array}{l}\text { whom polymeric } \\
\text { formulations are poorly } \\
\text { tolerated or contra- } \\
\text { indicated }\end{array}$} \\
\hline $\begin{array}{l}\text { 10.1 There is no } \\
\text { evidence to suggest } \\
\text { that either continuous } \\
\text { or intermittent/bolus } \\
\text { feeds are superior in } \\
\text { delivering gastric feeds } \\
\text { in critically ill children }\end{array}$ & $\begin{array}{l}\text { Deliver enteral feeds in the way your } \\
\text { unit usually does, based on your } \\
\text { availability of equipment (feeding } \\
\text { pumps) and your registered nurse to } \\
\text { patient staffing ratio } \\
\text { Post pyloric feeding cannot be } \\
\text { administered in bolus }\end{array}$ & $\begin{array}{l}\text { Nurses and } \\
\text { all }\end{array}$ & $\begin{array}{l}\text { Consider the number of feeding pumps available in your unit, } \\
\text { the nurse to patient ratio, the size of the child and their clinical } \\
\text { condition to choose the optimal delivery method }\end{array}$ \\
\hline $\begin{array}{l}11.1 \text { Gastric feeding is } \\
\text { as safe as post pyloric } \\
\text { feeding in the majority } \\
\text { of critically ill children }\end{array}$ & $\begin{array}{l}\text { Deliver enteral feeds in the way your } \\
\text { unit usually does }\end{array}$ & All & \\
\hline $\begin{array}{l}11.2 \text { Gastric feeding is } \\
\text { not inferior to post }\end{array}$ & $\begin{array}{l}\text { Deliver enteral feeds in the way your } \\
\text { unit usually does }\end{array}$ & All & \\
\hline
\end{tabular}




\begin{tabular}{|c|c|c|c|}
\hline $\begin{array}{l}\text { ESPNIC Clinical } \\
\text { Recommendations for } \\
\text { Nutritional Support in } \\
\text { PICU }\end{array}$ & Equipment and staff skills & $\begin{array}{l}\text { Staff } \\
\text { involved }\end{array}$ & Tools / other \\
\hline \multicolumn{4}{|l|}{$\begin{array}{l}\text { pyloric feeding in most } \\
\text { critically ill children }\end{array}$} \\
\hline $\begin{array}{l}11.3 \text { Post-pyloric } \\
\text { feeding can be } \\
\text { considered for critically } \\
\text { ill children at high risk } \\
\text { of aspiration or } \\
\text { requiring frequent } \\
\text { fasting for surgery or } \\
\text { procedures }\end{array}$ & $\begin{array}{l}\text { Which and how many staff in your } \\
\text { unit are trained to insert a post- } \\
\text { pyloric tube? } \\
\text { Do you have post-pyloric tubes readily } \\
\text { available? } \\
\text { Do you have written guidelines to } \\
\text { help improve insertion success? } \\
\text { Consider early which fasting are likely } \\
\text { to require frequent fasting eg severe } \\
\text { burns }\end{array}$ & All & $\begin{array}{l}\text { Link to nurse-led PP tube placement clinical guidelines } \\
\text { https://www.clinicalguidelines.scot.nhs.uk/ggc-paediatric- } \\
\text { guidelines/ggc-guidelines/intensive-and-critical-care/nurse-led- } \\
\text { blind-insertion-of-naso-jejunal-tube-in-picu/ } \\
\text { Or consider using an EMD device to optimise placement } \\
\text { https://journals.Iww.com/pccmjournal/Abstract/2009/03000/S } \\
\text { uccessful placement of postpyloric enteral tubes.8.aspx }\end{array}$ \\
\hline $\begin{array}{l}12.1 \text { Routine } \\
\text { measurement of GRV } \\
\text { in critically ill children is } \\
\text { not recommended }\end{array}$ & $\begin{array}{l}\text { Aspirating the gastric tube should only } \\
\text { be done to confirm feeding tube } \\
\text { position by ph. testing - aspirating the } \\
\text { whole stomach (GRV) is not necessary } \\
\text { to guide feeding, other parameters } \\
\text { should be used to assess 'feed } \\
\text { tolerance' } \\
\text { Education program for nurses may be } \\
\text { required } \\
\text { Enteral feeding protocols/flowcharts } \\
\text { may need changing }\end{array}$ & $\begin{array}{l}\text { Nurses and } \\
\text { all }\end{array}$ & 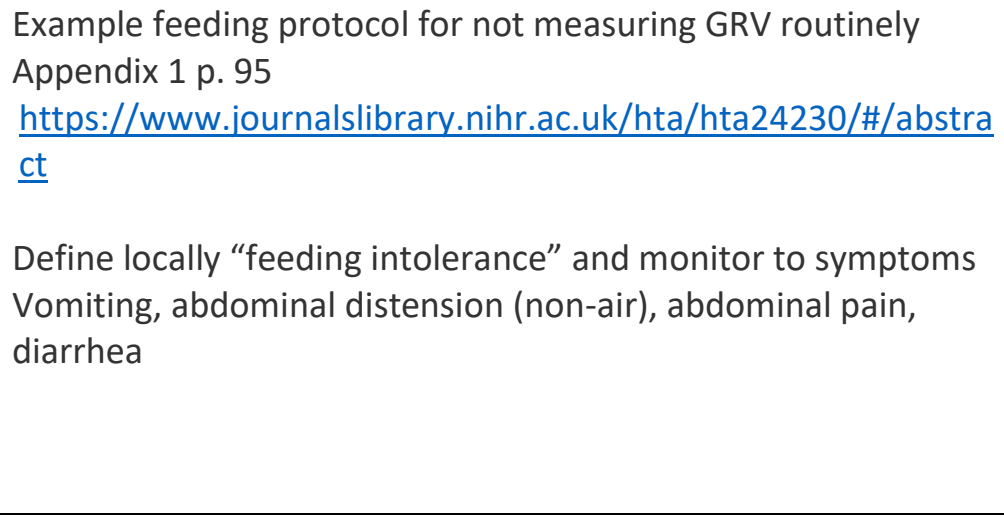 \\
\hline $\begin{array}{l}13.1 \text { There is } \\
\text { insufficient evidence to } \\
\text { support the use of } \\
\text { prokinetics in critically }\end{array}$ & Do not routinely prescribe prokinetics & $\begin{array}{l}\text { Physicians, } \\
\text { pharmacists }\end{array}$ & \\
\hline
\end{tabular}




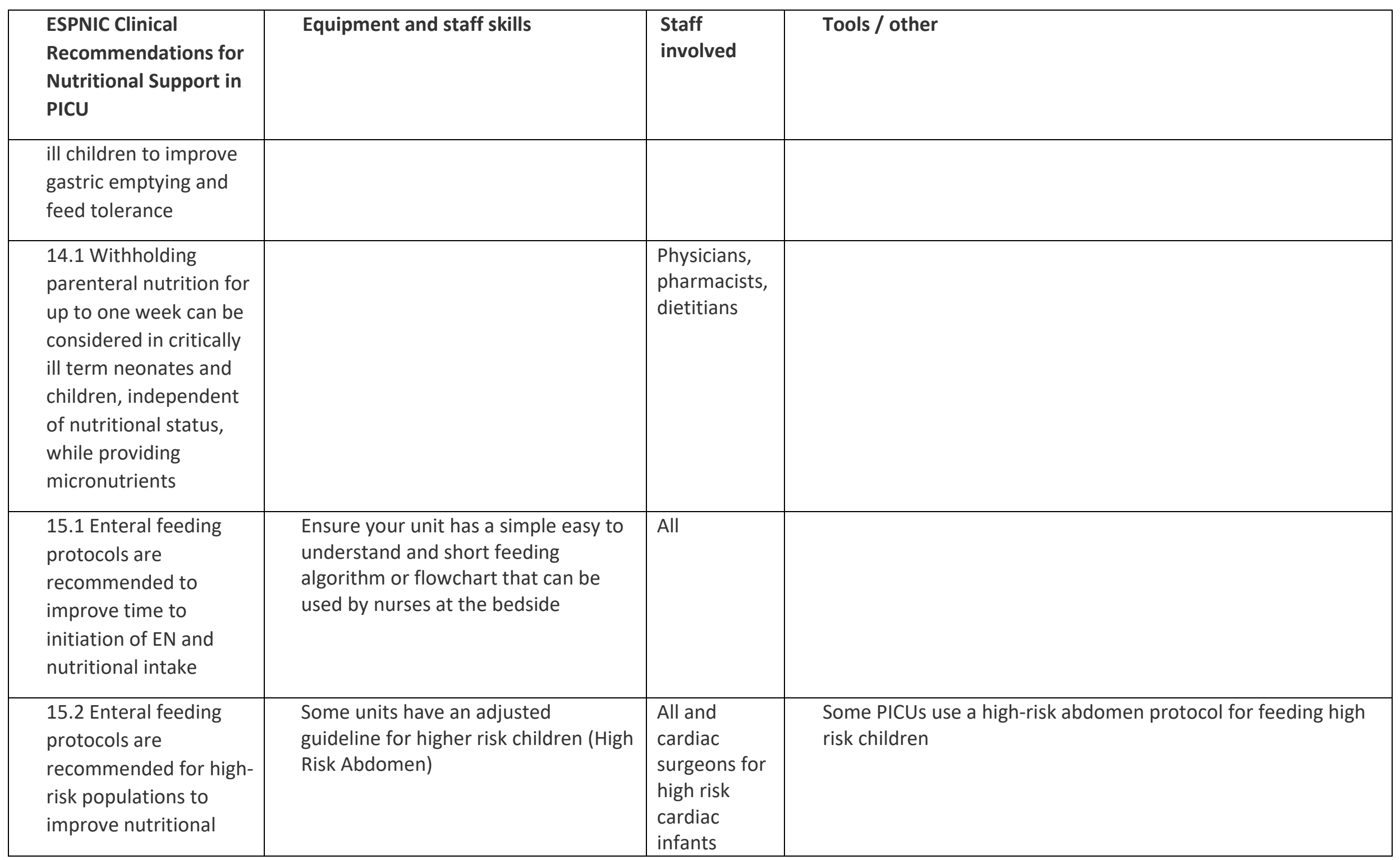




\begin{tabular}{|l|l|l|l|}
\hline $\begin{array}{l}\text { ESPNIC Clinical } \\
\text { Recommendations for } \\
\text { Nutritional Support in }\end{array}$ & Equipment and staff skills & $\begin{array}{l}\text { Staff } \\
\text { involved }\end{array}$ & Tools / other \\
PICU & & \\
\hline $\begin{array}{l}\text { intake and reduce } \\
\text { adverse events }\end{array}$ & & & \\
\hline
\end{tabular}

